\title{
Article \\ Protective Effect and Potential Antioxidant Role of Kakadu Plum Extracts on Alcohol-Induced Oxidative Damage in HepG2 Cells
}

\author{
Reshmi Akter ${ }^{1,+}$, Gi-Young Kwak ${ }^{1,+}$, Jong Chan Ahn ${ }^{1}$, Ramya Mathiyalagan ${ }^{1}\left(\mathbb{D}\right.$, Zelika Mega Ramadhania ${ }^{1}$, \\ Deok Chun Yang 1,2,*(D) and Se Chan Kang ${ }^{1, *(D)}$
}

check for

updates

Citation: Akter, R.; Kwak, G.-Y.; Ahn, J.C.; Mathiyalagan, R.; Ramadhania, Z.M.; Yang, D.C.; Kang, S.C. Protective Effect and Potential Antioxidant Role of Kakadu Plum Extracts on Alcohol-Induced Oxidative Damage in HepG2 Cells. Appl. Sci. 2022, 12, 236. https:// doi.org/10.3390/app12010236

Academic Editors: Dasha Mihaylova and Ivelina Desseva

Received: 6 December 2021

Accepted: 23 December 2021

Published: 27 December 2021

Publisher's Note: MDPI stays neutral with regard to jurisdictional claims in published maps and institutional affiliations.

Copyright: (c) 2021 by the authors. Licensee MDPI, Basel, Switzerland. This article is an open access article distributed under the terms and conditions of the Creative Commons Attribution (CC BY) license (https:// creativecommons.org/licenses/by/ $4.0 /)$.
1 Graduate School of Biotechnology, College of Life Sciences, Kyung Hee University, Yongin-si 17104, Gyeonggi-do, Korea; reshmiakterbph57@gmail.com (R.A.); kwakgiyoung8@gmail.com (G.-Y.K.); jongchanahn7@gmail.com (J.C.A.); ramyabinfo@gmail.com (R.M.); zelika.mega@unpad.ac.id (Z.M.R.)

2 Department of Oriental Medicinal Biotechnology, College of Life Sciences, Kyung Hee University, Yongin-si 17104, Gyeonggi-do, Korea

* Correspondence: dcyang@khu.ac.kr (D.C.Y.); sckang@khu.ac.kr (S.C.K.); Fax: +82-31-202-2688 (D.C.Y.)

+ These authors contributed equally to this work.

\begin{abstract}
Serial alcohol consumption causes alcoholic liver disease (ALD), which can lead to fatty liver, hepatitis, and cirrhosis. Terminalia ferdinandiana (Kakadu plum) is an indigenous fruit of Australia, which is utilized as a functional food. It is a commercially important antioxidant as it contains a more eloquent level of ascorbic acid than other oranges. In this study, we analyzed the chemical constituents of vitamin C, gallic acid, ellagic acid, and daidzin via High-performance liquid chromatography (HPLC) in the Kakadu plum from two different regions including the Northern Territory (NT) and Western Australia (WA), and compared their biochemical properties. The vitamin $\mathrm{C}$ content was much higher (almost 70\%) in Kakadu plum (KKD) from the NT than WA. Moreover, ROS generation was inhibited significantly in HepG2 (human hepatoma) cells with the KKD-NT extract treatment when compared to the KKD-WA extract treatment. The cytotoxicity produced by ethanol was significantly suppressed in response to the treatment with both of the samples. In addition, our samples (KKD-NT and KKD-WA) increased the activity of two key enzymes involving alcohol dehydrogenase (ADH) and aldehyde dehydrogenase (ALDH) that metabolize ethanol. These results show the biochemical confirmation of the mechanism by which KKD exhibits its biological functions including relief from alcohol hangovers as well as protection of the liver cells by the suppression of ROS production and toxic insults.
\end{abstract}

Keywords: Kakadu plum; ethanol metabolism; liver; toxicity; ROS generation

\section{Introduction}

A moderate amount of alcohol can promote the body's metabolism rate and reduce the risk of cardiovascular difficulties. However, long-term, heavy alcohol consumption can cause hangovers and other health issues including hepatitis, liver cirrhosis and fatty liver, muscle pain, etc. [1-3]. A meta-analysis and case-cohort study indicated that heavy alcohol drinking is associated with being a major risk factor for gastric cancer [4,5]. In 2014, gastric cancer was the second most common cause of morbidity and the third most common cause of mortality in South Korea [6]. Numerous mechanisms are known to explain alcoholinduced hepatotoxicity, among these, the generation of reactive oxygen species (ROS) leads to oxidative stress, which is one of the most extensively studied mechanisms [7,8]. In addition, the antioxidant level of the liver cells is inhibited by ethanol-induced oxidative stress $[9,10]$.

Liver is a primary organ that regulates alcohol metabolism as it contains an abundant amount of alcohol metabolizing enzymes [11]. Alcohol can be metabolized by oxidative 
and non-oxidative pathways in the liver [12]. These pathways involve several enzymes such as alcohol dehydrogenase (ADH), aldehyde dehydrogenase (ALDH), microsomal ethanol oxidizing system (MEOS, CYP2E1), and catalase (less significant) [13]. The most important pathway for alcohol metabolism is represented by alcohol dehydrogenase and acetaldehyde dehydrogenase enzymes widely distributed in the liver. ADH enzymes oxidize ethanol into acetaldehyde, which is broken down further into acetate by ALDH enzymes [14,15]. In addition, the chronic use of alcohol promotes the production of ROS [16]. Moreover, in mitochondria, NADH is reoxidized into NAD+, which causes an imbalance in the intracellular redox state that leads to an increase in oxidative stress [17]. The excessive consumption of alcohol also increases the activity of cytochrome P450 2E1 (CYP2E1) but not ADH, and this activated enzyme can produce acetaldehyde via the formation of ROS [18]. Large amounts of ROS can cause cellular dysfunction and could eventually lead to cell death [19]. In higher concentrations, both acetaldehyde and ROS can cause harmful effects such as nausea, vomiting, sweating, and a rapid pulse. Therefore, it is important to eliminate excess ethanol and acetaldehyde from our body to prevent severe liver damage [20].

For thousands of years, herbal remedies have been used to cure alcoholic disorders in several cultures. Terminalia ferdinandiana, commonly known as the Kakadu plum (KKD), is traditionally the most popular fruit in Australian Aboriginal populations. KKD is found mostly in the Northern Territory (NT) and Western Australia (WA), and is considered to be a medicine rather than food by certain tribes [21-23]. In WA, KKD is known as the bush plum, billygoat plum, gubinge, and Nyaninyari [3]. In the NT, the Aboriginal people use this fruit as an important commercial product to provide them with a livelihood [23]. The KKD was traditionally used as a refreshing drink for children and adults in WA: it was consumed for energy and refreshment on hunting trips [24]. The fruit contains a large amount of vitamin C (L-ascorbic acid) along with a wide range of phytochemicals, such as phenolic compounds and flavonoids, which includes gallotannins, ellagitannins, phenolic acids, proanthocyanidins, ellagic and gallic acid [25,26]. T. ferdinandiana is a potential antioxidant [27-29] and possesses pharmacological activities against cancer [30], rheumatoid arthritis [31], inflammation [32], bacteria [33], and so on. An investigation revealed that ascorbic acid from $T$. ferdinandiana has a protective effect against the chronic toxicity of acetaldehyde, which arises from heavy alcohol drinking. In contrast, the levels of ascorbic acid in the body are known to be lowered in alcoholics [34]. However, the protective mechanism of KKD on ethanol metabolism have not yet been reported. In this study, we focused on developing an in vitro model to investigate the protective effect of the KKD from two states of Australia (KKD-NT and KKD-WA) against ethanol (ETOH)induced cytotoxicity in HepG2 cells. We also investigated the effects of the KKD fruit on two key enzymes (ADH and ALDH) with regard to alcohol metabolism along with the antioxidant effect of the KKD on alcohol-induced HepG2 cells.

\section{Materials and Methods}

\subsection{Chemical and Reagents}

HepG2 cells, a human liver cancer cell line, were obtained from ATCC. Roswell Park Memorial Institute Medium (RPMI 1640) (GenDEPOT Inc Katy, TX, USA.) and 10\% fetal bovine serum (FBS) were purchased from Welgene (Daegu, Korea); penicillin and streptomycin (P/S) were obtained from GenDEPOT. Dimethyl sulfoxide (DMSO), 30-(4,5dimethylthiazole-2yl)-2,5-diphenyltetrazolium bromide (MTT), and nicotinamide adenine dinucleotide (NAD) were obtained from Sigma Chemical Co. (St. Louis, MO, USA).

\subsection{Collection of Fruit Materials}

T. ferdinandiana (Kakadu plum) grows across huge areas in two states of Australia including the Northern Territory (NT) and Western Australia (WA). The different environmental conditions in WA and NT may affect the accumulation of secondary metabolites in the fruit. Therefore, our study investigated the individual efficacy of the Kakadu plum 
from the two different states on alcoholism. For our study, the native Australian fruit (T. ferdinandiana) from the Northern Territory (KKD-NT) were provided by KAKADU LIFE NT (Canning Vale, Australia) and the fruit from Western Australia (KKD-WA) were provided by KIMBERLEY WILD GUBINGE (Kimberley, Australia) as dried fruits.

Pomegranate was purchased from POM wonderful LLC (Los Angeles, CA, USA), oranges and lemons were obtained from Sunkist Growers Inc. (Ontario, CA, USA), blueberries and raspberries were purchased from WOOYANG CO.LTD (Seocheon-gun, Korea): these fruits were collected as fresh fruits. We selected these fruits as they are a common source of vitamin $C$ and are commercial products that are readily available for people to purchase in markets.

\subsection{Extract Preparation}

The fresh fruits, pomegranate, lemons, oranges, blueberries, and raspberries were dried for 3 days in a hot air oven $\left(60^{\circ} \mathrm{C}\right)$. These dried fruits and the dried Kakadu plum fruits (KKD-NT and KKD-WA) were then separately ground using a blender to optimize the extraction process. The extraction of all fruit samples was accomplished by the reflux method. Briefly, $2 \mathrm{~g}$ of powdered sample was boiled with $40 \mathrm{~mL}$ of water for $2 \mathrm{~h}$ at $95{ }^{\circ} \mathrm{C}$ with three repetitions. Whatman filter paper no. 41 was used to filter the mixture in each processing time and the cooled filtrate was collected. Then, the solvent was evaporated through rotary evaporator. Finally, to determine the extraction yield from the crude fruit, extracts were collected and weighed.

\subsection{HPLC System and Condition for Analysis of Chemical Contents of Fruits}

Before loading into the high-performance liquid chromatography (HPLC) system, the supernatant obtained after centrifugation was passed through $0.45 \mu \mathrm{m}$ syringe filter. The HPLC system condition for analyzing vitamin C, phenolic compounds, and isoflavones is shown in (Table 1) below:

Table 1. HPLC system and condition for analysis of vitamin C, phenolic acids, and isoflavones.

\begin{tabular}{|c|c|c|c|}
\hline \multirow[b]{2}{*}{ System/Condition } & \multicolumn{3}{|c|}{ Compound } \\
\hline & Vitamin C & $\begin{array}{c}\text { Phenolic Acids (Gallic Acid } \\
\text { and Ellagic Acid) }\end{array}$ & Isoflavones (Daidzin) \\
\hline Flow rate & $1.0 \mathrm{~mL} / \mathrm{min}$ & $1.0 \mathrm{~mL} / \mathrm{min}$ & $0.8 \mathrm{~mL} / \mathrm{min}$ \\
\hline Wavelength & $254 \mathrm{~nm}$ & $260 \mathrm{~nm}$ & $254 \mathrm{~nm}$ \\
\hline Injection Volume & $10 \mu \mathrm{L}$ & $5 \mu \mathrm{L}$ & $10 \mu \mathrm{L}$ \\
\hline Solvents & $\begin{array}{c}\text { Gradient eluent: } \\
\text { A: } 0.1 \% \text { Acetic acid in water } \\
\text { B: } 0.1 \% \text { Acetic acid } \\
\text { in methanol/water }(90: 10)\end{array}$ & $\begin{array}{l}\text { Gradient eluent: } \\
\text { A: Methanol } \\
\text { B: } 0.1 \% \text { Acetic acid } \\
\text { in water }\end{array}$ & $\begin{array}{c}\text { Gradient eluent: } \\
\text { A: } 0.1 \% \text { Acetic acid in water } \\
\text { B: Acetonitrile }\end{array}$ \\
\hline Column Temperature & $25^{\circ} \mathrm{C}$ & $35^{\circ} \mathrm{C}$ & $35^{\circ} \mathrm{C}$ \\
\hline
\end{tabular}

The Agilent 1260 Infinity Quaternary Pump (G1311B), Agilent 1260 Infinity Standard Autosampler (G1329B), Agilent 1260 Infinity Column Thermostat Compartment (G1316A), and Agilent 1260 Infinity Variable Wavelength Detector (G1314F) made up the instrument system, and ZORBAX Eclipse Plus C18 column $(250 \mathrm{~mm} \times 4.6 \mathrm{~mm}, 5 \mu \mathrm{m}$ particle size) (Milford, MA, USA) was chosen as a stationary phase. For vitamin C (L-ascorbic acid) analysis, the eluent composition was as follow: (0-5 $\mathrm{min}, 0.5 \% \mathrm{~B} ; 5-12 \mathrm{~min}, 90 \% \mathrm{~B} ; 12-12.5 \mathrm{~min} 0.5 \%$ $\mathrm{B} ; 12.5-15 \mathrm{~min}, 0.5 \% \mathrm{~B})$. The respective gradient elution compositions for phenolic acids and isoflavones were as follows: (0-8 min, 90-80\% B; 8-30 min, 80-55\% B; 30-60 min, 55-30\% B) and (0-16 min, 15-30\% B; 16-34 min, 30-100\% B; 34-40 min, 100-100\% B; 40-41 min, $100-15 \%$ B; 41-42 min 15-15\% B), results shown in (Table 2). To validate the HPLC quan- 
titative data in terms of linearity, the Limit of Detection (LOD), Limit of Quantification (LOQ), and recovery tests (Table 3) were applied according to Mohapatra et al., 2021 [35].

Table 2. Total amount of vitamin C, phenolics, total flavonoids of KKD-NT and KKD-WA and other fruits.

\begin{tabular}{ccccccc}
\hline Samples & $\begin{array}{c}\text { Vitamin C } \\
\text { (L-Ascorbic Acid) } \\
(\mathbf{m g} / \mathbf{g} \text { DW) }\end{array}$ & $\begin{array}{c}\text { Gallic Acid } \\
\mathbf{( m g / g} \text { DW) }\end{array}$ & $\begin{array}{c}\text { Ellagic Acid } \\
\mathbf{( m g / g ~ D W ) ~}\end{array}$ & $\begin{array}{c}\text { Daidzin } \\
\text { (mg/g DW) }\end{array}$ & $\begin{array}{c}\text { Total Phenolics } \\
\text { (mg GAE/g } \\
\text { DW *) }\end{array}$ & $\begin{array}{c}\text { Total Flavonoids } \\
\text { (mg QE/g DW **) }\end{array}$ \\
\hline KKD-NT & $88.66 \pm 2.92$ & $3.67 \pm 0.16$ & $0.11 \pm 0.02$ & $0.05 \pm 0.01$ & $147.2 \pm 0.70$ & $1.30 \pm 0.01$ \\
KKD-WA & $52.83 \pm 1.85$ & $5.10 \pm 0.03$ & $0.36 \pm 0.01$ & $0.04 \pm 0.00$ & $115.2 \pm 2.12$ & $1.10 \pm 0.02$ \\
Pomegranate & $\mathrm{T}$ & $0.13 \pm 0.00$ & $0.01 \pm 0.00$ & $0.01 \pm 0.00$ & $16.66 \pm 1.32$ & $0.32 \pm 0.02$ \\
Orange & $0.03 \pm 0.00$ & $\mathrm{~T}$ & $\mathrm{ND}$ & $\mathrm{ND}$ & $27.01 \pm 1.14$ & $0.94 \pm 0.03$ \\
Lemon & $0.11 \pm 0.00$ & $\mathrm{~T}$ & $\mathrm{~T}$ & $\mathrm{ND}$ & $19.52 \pm 0.84$ & $0.66 \pm 0.01$ \\
Blueberry & $\mathrm{T}$ & $\mathrm{T}$ & $\mathrm{ND}$ & $\mathrm{T}$ & $21.96 \pm 1.58$ & $0.86 \pm 0.06$ \\
Raspberry & $0.01 \pm 0.00$ & $\mathrm{~T}$ & $0.02 \pm 0.00$ & $\mathrm{~T}$ & $25.79 \pm 2.47$ & $0.63 \pm 0.03$ \\
\hline
\end{tabular}

* mg GAE/g DW: mg gallic acid equivalents (mg GAE)/g dry weight (DW) of fruits; ** mg QE/g DW: mg quercetin equivalents $(\mathrm{mg} \mathrm{QE}) / \mathrm{g}$ dry weight (DW) of fruits.

Table 3. Parameter of calibration curves and recovery rates of the reference standard compounds.

\begin{tabular}{|c|c|c|c|c|c|c|c|}
\hline Standard & Solvent & $\begin{array}{l}\text { Regression } \\
\text { Equations }\end{array}$ & $\mathbf{R}^{2}$ & $\begin{array}{c}\text { LOD } \\
(\mathrm{mg} / \mathrm{mL})\end{array}$ & $\begin{array}{c}\text { LOQ } \\
(\mathrm{mg} / \mathrm{mL})\end{array}$ & $\begin{array}{c}\text { Recovery } \\
(\%)\end{array}$ & $\begin{array}{c}\text { RSD } \\
(\%)\end{array}$ \\
\hline L-Ascorbic acid & $0.1 \%(v / v) 1 \mathrm{M} \mathrm{HCL}$ & $y=20,641 x+99$ & 0.99998 & 2.01 & 6.71 & 99.13 & 0.24 \\
\hline Gallic acid & & $y=14,948 x+113.86$ & 0.99971 & 1.75 & 5.84 & 99.87 & 0.08 \\
\hline Ellagic acid & Methanol & $y=43,616 x-34.482$ & 0.99999 & 0.57 & 1.90 & 99.35 & 0.12 \\
\hline Daidzin & & $y=86,955 x-72.593$ & 0.99981 & 0.39 & 1.31 & 98.50 & 0.45 \\
\hline
\end{tabular}

LOD = Limit of Detection; LOQ = Limit of Quantitation; RSD = Relative Standard Deviation.

\subsection{Cell Culture and Treatment}

HepG2 cells were grown in the culture medium RPMI 1640 with 10\% FBS and 1\% penicillin. Cells were cultured in a humidified incubator at $37^{\circ} \mathrm{C}$ with $5 \% \mathrm{CO}_{2}$ atmosphere. Approximately $1.0 \times 10^{4}$ cells $/ \mathrm{cm}^{2} \mathrm{HepG} 2$ cells were seeded in a 96-well plate and grown to reach $80 \%$ confluency in the $\mathrm{CO}_{2}$ incubator. Post confluent cells were co-treated with $4 \%$ ethanol with or without KKD-NT and KKD-WA of different concentrations $(20-100 \mu \mathrm{g} / \mathrm{mL})$ for $24 \mathrm{~h}$.

\subsection{Cell Viability Test}

Cell survival rate was investigated using MTT assay. It is a yellow dye, which leads to the formation of the blue product formazan crystals that accumulate within the cells. Briefly, $20 \mu \mathrm{L}$ of MTT solution was put into each well and the reaction was incubated for 2 to $3 \mathrm{~h}$. Cells were then stained with $100 \mu \mathrm{L}$ of DMSO to dissolve the insoluble formazan crystals into a colored solution, and cell survival rate was taken at $570 \mathrm{~nm}$ using an enzymelinked immunosorbent assay (ELISA) reader (Bio-Tek Instruments, Inc., Winooski, VT, USA) according to the procedure described by Simu et al. [36].

\subsection{DPPH Scavenging Assay}

DPPH method was used to evaluate the free radical scavenging activity of tested samples with the slight modification from the previous method [37]. A total of $0.2 \mathrm{M} \mathrm{DPPH}$ was dissolved with analytical grade ethanol for DPPH radical solution. In 96-well plate, $20 \mu \mathrm{L}$ of extract and $180 \mu \mathrm{L}$ of DPPH solution were added and then shaken vigorously in the dark for $30 \mathrm{~min}$ at $25^{\circ} \mathrm{C}$. Different concentrations of KKD-NT and KKD-WA (100, 200, $400,600,800$, and $1000 \mu \mathrm{g} / \mathrm{mL}$ ) were adopted to obtain IC50. The absorbance was assessed at $517 \mathrm{~nm}$. The percentage inhibition of the samples was calculated by using the formula: (1-Absorbance of sample/Absorbance of control) * 100 . 


\subsection{Protocol for Reducing Power Activity}

The transformation of the $\mathrm{Fe}^{3+}$ to $\mathrm{Fe}^{2+}$ was investigated in the presence of KKD extracts for the measurement of the reductive ability following the standard method [38]. The reducing capacity of a component indicates significance of its possible antioxidant activity.

In total, $100 \mu \mathrm{L}$ of selected concentrations of tested samples were put together with $250 \mu \mathrm{L}$ of phosphate buffer with a $\mathrm{pH} 6.6$ and $250 \mu \mathrm{L}$ of $(1 \%)$ potassium ferricyanide. Then, we incubated the mixture at $50{ }^{\circ} \mathrm{C}$ in water bath for $20 \mathrm{~min}$. A total of $250 \mu \mathrm{L}$ of $(10 \%)$ trichloroacetic acid was added to the mixture after cooling. Then, the mixture was centrifuged at $8000 \mathrm{rpm}$ for $10 \mathrm{~min}$. The top layer of solution was mixed with $100 \mu \mathrm{L}$ distilled water and $20 \mu \mathrm{L}$ of $(0.1 \%)$ ferric chloride solution, which was prepared instantly. The absorbance was assessed at $700 \mathrm{~nm}$. In the assay, ascorbic acid and gallic acid were used as standards. A blank was performed without adding extracts. The reducing power increases with the increase in absorbance of the reaction mixture. The results are exhibited in $\mathrm{mg}$ of ascorbic acid and gallic acid equivalents per gram (mg AAE/g DW or mg GAE/g DW) of sample.

\subsection{Measurement of Cellular ROS}

$2^{\prime}, 7^{\prime}$-dichlorofluorescin diacetate (H2DCFDA) is a non-polar compound and cell permeable fluorogenic probe that is used to quantify the extent of ROS formation within cells. After entering in cells, H2DCFDA can be hydrolyzed into polar form $2^{\prime}, 7^{\prime}$-dichlorodihydrofluorescein (DCFH). In total, $1 \times 10^{4}$ cells / well cells were seeded in 96-well dark plates. Cells were then serum starved with serum-free medium, and then the cells were treated with the dried Kakadu fruits (KKD-NT and KKD-WA) in the presence or absence of $4 \%$ ethanol for $24 \mathrm{~h}$. The cells were washed twice with ice-cold phosphate buffered saline (PBS) after the incubation with $10 \mathrm{mM} \mathrm{H} 2 \mathrm{DCFDA}$ at $37^{\circ} \mathrm{C}$ in darkness for $30 \mathrm{~min}$. After the PBS washing, the fluorescence intensity was measured at excitation and emission wavelengths of 485 and $495 \mathrm{~nm}$, respectively, with a Spectra Fluor multiwell fluorescence reader (Tecan, Maninder, Austria) according to Castro-Aceituno et al. [39].

\subsection{Measurement of Cellular ADH Activity}

The ADH activity was measured with minor modifications as described [40]. In brief, human hepatoma HepG2 cells were seeded in a 6-well pate at $1.0 \times 10^{5}$ cells / well for $24 \mathrm{~h}$. Then, the cells were kept incubated with medium containing $4 \%$ ethanol with or without KKD-NT and KKD-WA for $24 \mathrm{~h}$. The medium was removed at incubated time points and cells were lysed with $1 \%$ Triton-X 100. The ADH activity was evaluated in the supernatant at $340 \mathrm{~nm}$. ADH assay was quantified by using the reaction mixture that consists of $0.25 \mathrm{M}$ Tris- $\mathrm{HCl}$ ( $\mathrm{pH} 8.8), 2.8 \mathrm{mM}$ NAD+, $100 \mathrm{mM}$ ethanol along with cell supernatant. After the incubation of the reaction mixture at $30{ }^{\circ} \mathrm{C}$ for $5 \mathrm{~min}$ absorbance at $340 \mathrm{~nm}$ was measured to verify the NADH production rate.

\subsection{Measurement of Cellular ALDH Activity}

HepG2 cells were seeded in a 6-well pate at $1.0 \times 10^{5}$ cells/well for $24 \mathrm{~h}$. Then, the cells were kept in incubator for $24 \mathrm{~h}$ with medium containing $4 \%$ ethanol with or without KKD-NT and KKD-WA. The medium was removed at incubated time points and cells were lysed with $1 \%$ Triton-X 100 . The ALDH activity was measured in the supernatant at $340 \mathrm{~nm}$ as described [41]. The reaction mixture prepared for the ALDH assay contained $0.25 \mathrm{M}$ Tris$\mathrm{HCl}$ (pH 8.8), 2.8 mM NAD+, $0.03 \mathrm{M}$ acetaldehyde, $0.1 \mathrm{M} \mathrm{KCl}, 0.01 \mathrm{M}$ 2-mercaptoethanol along with cell supernatant. The production rate of NADH from NAD+ was determined at $340 \mathrm{~nm}$ after incubation at $30^{\circ} \mathrm{C}$ for $5 \mathrm{~min}$.

\subsection{Statistical Analysis}

All data were reported as mean \pm SE calculated from at least three independent experiments. The total variations between treated and untreated (control) groups were 
estimated by Student's t-test and two-way analysis of variance (ANOVA). The differences were considered significant at $p<0.05, p<0.01$, and $p<0.001$, respectively.

\section{Results and Discussion}

\subsection{Analysis of Vitamin C, Gallic Acid, Ellagic Acid, and Daidzin Using HPLC}

Ellagic acid and vitamin $C$ have been widely reported to be present in the Kakadu plum fruit, and these provide the major functional elements of and are responsible for the antioxidant activity [42]. The quantification of vitamin C, ellagic acid, and phenolic acid along with flavonoids was performed using HPLC. Table 2 demonstrates the amount of ellagic acid present in our fruit samples, ranging from $0.01 \pm 0.00$ to $0.36 \pm 0.01 \mathrm{mg} / \mathrm{g}$ $\mathrm{DW}$, whereas gallic acid varies from $0.13 \pm 0.00$ to $5.10 \pm 0.03 \mathrm{mg} / \mathrm{g} \mathrm{DW}$. Recently, other literature has recorded the presence of a significant amount of ellagic acid and ascorbic acid in the Kakadu plum [43].

T. ferdinandiana, the Kakadu plum (KKD), is well known as a source of vitamin C (mainly known as ascorbic acid) [28]. According to previous studies, the Kakadu plum contains 75 times more vitamin C than oranges [43]. Vitamin C, or ascorbic acid, is a dietary antioxidant that is necessary for humans, which can easily be degraded in the presence of excessive heat, water, and air $[44,45]$. Though the drying process and reflux were our choice for the extraction method in this study, the aqueous extract of KKD from the NT still exhibited the highest amount of vitamin C compared with the KKD from WA. Dry weights of $88.66 \pm 2.92 \mathrm{mg} / \mathrm{g}$ and $52.83 \pm 1.85 \mathrm{mg} / \mathrm{g}$ of vitamin $\mathrm{C}$ were determined from KKD-NT and KKD-WA, respectively. According to previous reports, the Kakadu plum has a higher level of ascorbic acid (vit-C) than other domestic fruits, and 900 times more ascorbic acid than blueberries $[44,45]$. Moreover, it has been reported that KKD contains a much larger amount of vitamin $C$ than common natural sources of vitamin $C$ such as lemons and oranges [46]. Although lemons and oranges are common sources of vitamin C, our results showed a smaller amount of vitamin $C$ in those fruits than in the Kakadu plum, which may due to the extraction of the samples at a higher temperature. It is known that vitamin $\mathrm{C}$ can degrade easily at high temperatures. However, despite their extraction at higher temperatures, the vitamin $C$ content in KKD did not degrade significantly. According to previous reports, KKD contains $7000 \mathrm{mg} / 100 \mathrm{~g}$ DW of vitamin C, which is 100 times higher than the amount in lemons and oranges [47].

Furthermore, in comparison to other fruits, our results showed that KKD possesses a much higher amount of vitamin C. To enhance the benefits of the Kakadu plum as a source of phytonutrients, its isoflavones profile was examined. Based on the results (Table 2), daidzin was present only in the Kakadu plum and pomegranate, while in the other samples it was not detected or was present in only a trace amount.

\subsection{Total Phenolic and Flavonoid Contents}

Phenolics and flavonoids are the major secondary metabolites of plants that protect plant cells from oxidative damage and environmental stress [48]. The Folin-Ciocalteu and aluminum chloride colorimetric methods were used, respectively, to estimate the total phenolic (TPC) and flavonoid (TFC) contents of the fruit extracts including KKD-NT and KKD-WA, as shown in (Table 2).

The contents varied widely, ranging from $16.66 \pm 1.32$ to $147.2 \pm 0.70 \mathrm{mg} / \mathrm{g}$, expressed as gallic acid equivalents (GAE), and from $0.32 \pm 0.02$ to $1.30 \pm 0.01 \mathrm{mg} / \mathrm{g}$, expressed as quercetin equivalents $(\mathrm{QE})$. A previous study reported that phenolic compounds are significantly higher in KKD than blueberries [49]. In this study, KKD showed higher levels of phenolics and flavonoids than the other tested fruits as measured in gallic acid and quercetin equivalent standards. KKD-NT exhibited significantly larger amounts of total phenolic and flavonoid content than KKD-WA, followed by pomegranate, oranges, lemons, blackberries, and raspberries. This clearly shows that the Kakadu plum is one of the richest sources of phenolic and flavonoid content in edible fruits. 


\subsection{Antioxidant Activity of Plant Extracts: DPPH and Reducing Power Assays}

In the present study, we selected five different fruits in addition to a native Australian fruit, the Kakadu plum (T. ferdinandiana), to examine their antioxidant potential. Various assays are available to quantify antioxidant capacity and, from these, we chose DPPH and the potassium ferricyanide reducing power assay to evaluate the antioxidant potential of our samples, expressed as gallic acid equivalents (GAE) and ascorbic acid equivalents (AAE). These assays are used widely to determine the antioxidant properties of compounds as free radical scavengers or hydrogen donors [50], and the results are shown in (Table 4)

Table 4. Potential antioxidant activities of KKD-NT and KKD-WA.

\begin{tabular}{ccccc}
\hline \multirow{2}{*}{ Samples } & \multicolumn{2}{c}{ DPPH } & \multicolumn{2}{c}{ Reducing Power } \\
\cline { 2 - 5 } & $\mathbf{( m g ~ G A E / g ~ D W ) ~}$ & $\mathbf{( m g ~ A A E / g ~ D W ) ~}$ & $\mathbf{( m g ~ G A E / g ~ D W ~ * ) ~}$ & (mg AAE/g DW **) \\
\hline KKD-NT & $239.7 \pm 8.17$ & $124.4 \pm 4.34$ & $179.6 \pm 5.35$ & $74.4 \pm 2.06$ \\
KKD-WA & $215.9 \pm 16.2$ & $111.1 \pm 8.60$ & $140.6 \pm 7.80$ & $60.5 \pm 3.08$ \\
Pomegranate & $2.19 \pm 0.02$ & $5.27 \pm 0.04$ & $7.22 \pm 0.12$ & $15.29 \pm 0.23$ \\
Orange & $1.16 \pm 0.02$ & $2.60 \pm 0.04$ & $8.75 \pm 0.30$ & $18.14 \pm 0.56$ \\
Lemon & $1.66 \pm 0.08$ & $2.47 \pm 0.05$ & $6.65 \pm 0.44$ & $14.08 \pm 0.83$ \\
Blueberry & $2.84 \pm 0.01$ & $6.86 \pm 0.03$ & $8.94 \pm 0.33$ & $18.86 \pm 0.61$ \\
Raspberry & $3.29 \pm 0.03$ & $8.13 \pm 0.07$ & $11.76 \pm 0.20$ & $23.79 \pm 0.37$ \\
\hline
\end{tabular}

${ }^{*}$ mg AAE/g DW: $\mathrm{mg}$ ascorbic acid equivalents (mg AAE)/ g dry weight (DW); ${ }^{* *} \mathrm{mg} \mathrm{GAE/g} \mathrm{DW:} \mathrm{mg}$ gallic acid equivalents (mg GAE)/ g dry weight (DW) of fruits.

The results of the DPPH assay revealed that the antioxidant capacity of the fruits ranged from $1.16 \pm 0.02$ to $239.7 \pm 8.17 \mathrm{mg} / \mathrm{g}$, expressed as GAE, and varied from $2.47 \pm 0.05$ to $124.4 \pm 4.34 \mathrm{mg} / \mathrm{g}$, expressed as AAE. Similarly, the reducing power assay recorded that, in comparison with all fruit samples, KKD-NT and KKD-WA showed the highest antioxidant properties, ranging from $6.65 \pm 0.44$ to $179.6 \pm 5.35 \mathrm{mg}$ GAE/g DW and from $14.08 \pm 0.83$ to $74.4 \pm 2.06 \mathrm{mg} \mathrm{AAE} / \mathrm{g}$ DW. The IC50 value was calculated to determine the concentration of the sample required to inhibit $50 \%$ of the free radical. The lower the IC50 value, the higher the antioxidant activity of samples [51]. The half-maximal inhibitory concentration (IC50) value of the KKD-NT extract was $170.6 \mu \mathrm{g} / \mathrm{mL}$, whereas KKD-WA showed an IC50 value of $272.9 \mu \mathrm{g} / \mathrm{mL}$. We examined whether the scavenging capacities for KKD-NT and KKD-WA were extended dose-dependently (Figures 1 and 2) and the KKD-NT extract displayed potent antioxidant and reducing power activities compared with those measured for the KKD-WA extract and the other fruits (pomegranate, lemon, orange, blueberry, and raspberry). According to a previous study, it was also proven that the Kakadu plum contains a higher level of antioxidant potential in comparison to blueberries as strong fat-soluble antioxidants are present in the Kakadu plum [51].

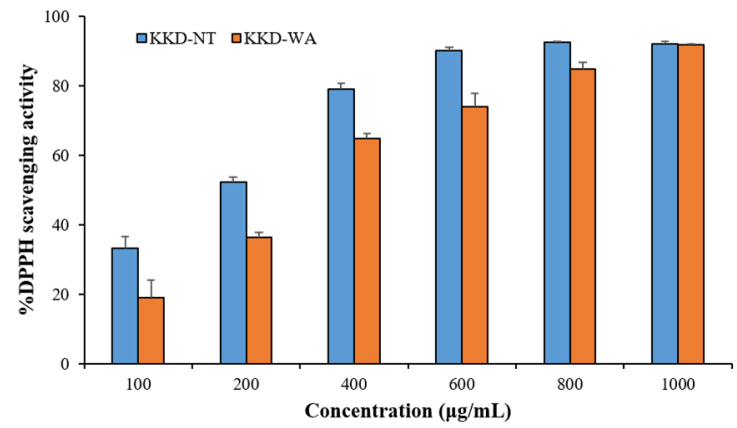

Figure 1. DPPH scavenging activity of KKD-NT and KKD-WA.

\subsection{Ethanol Induces Cell Death}

To evaluate the protective effect of the Kakadu plum on alcohol-induced cell death the optimal concentration of ethanol was measured in the hepatocellular carcinoma cell line 
(HepG2). For that, we treated HepG2 cells with indicated concentrations of ethanol $(0.25 \%$ to $8 \%$ ) for $24 \mathrm{~h}$, and then subjected them to MTT reagent to measure the cell survival rate. The HepG2 cell line is commonly used as a common model to assess the toxicity studies of various compounds against an oxidative stress inducer [52]. The viability of the cell in percentage showed a gradual decrease with the increasing concentration of ethanol in the HepG2 cells treated for $24 \mathrm{~h}$. At a concentration of $4 \%$ ethanol, almost half of the cells were inhibited in comparison with the control group (0\%) in HepG2 cells. Therefore, we selected $4 \%$ ethanol to induce cell inhibition in the HepG2 cells to examine the prevention of cell death by the extracts of Kakadu plum and to study the prevention of ethanol-induced ROS production by our samples.

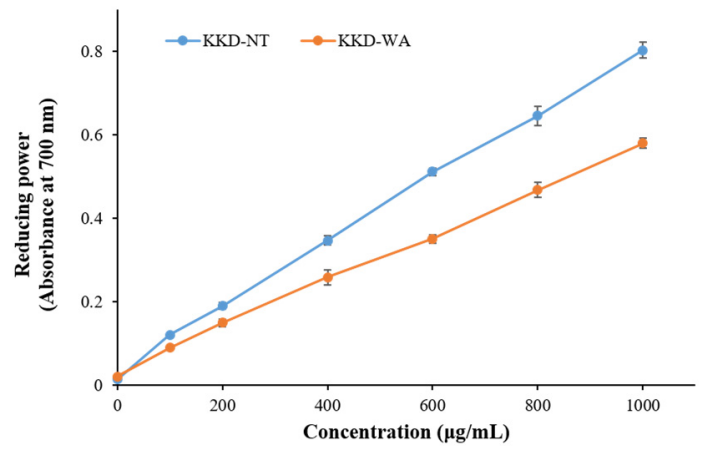

Figure 2. Reducing power activity of KKD-NT and KKD-WA.

\subsection{Kakadu Plum Protects HepG2 Cells from Ethanol-Induced Cell Death}

The HepG2 cells were incubated with independent concentrations of KKD-NT and KKD-WA, which were nearly non-toxic with a concentration up to $200 \mathrm{mg} / \mathrm{mL}$ (Figure 3). In this study, we decided to conduct all subsequent experiments below the concentration of $200 \mathrm{mg} / \mathrm{mL}$ (20-100 mg/mL). According to the HPLC analysis, our samples contained an abundant amount of vitamin $\mathrm{C}$, which can protect cells from oxidative damage by ROS reduction. However, higher levels of ascorbic acid (Vit-C) show cytotoxicity by generating excessive ROS as well as blocking the energy homeostasis on cancerous cells [53]. To explore the protective effect of KKD-NT and KKD-WA against ethanol-induced cell toxicity (Figure 4a), HepG2 cells were co-treated with $4 \%$ ethanol with or without KKD-NT and KKD-WA $(0-100 \mu \mathrm{g} / \mathrm{mL})$ for $24 \mathrm{~h}$, and then the cell survival ratio was examined by MTT assay. KKD-NT and KKD-WA significantly inhibited the cytotoxicity of EtOH in a dosedependent manner (Figure $4 \mathrm{~b}$ ). EtOH decreased the cell survival rate by close to $50 \%$ compared to the untreated cells, whereas the cell viability was dose-dependently increased in the KKD extracts co-treatment. The viability of the $100 \mu \mathrm{g} / \mathrm{mL}$ Kakadu-treated group increased significantly, indicating the protective effect of KKD-NT and KKD-WA against the cytotoxicity of EtOH. Cell viability was evidently elevated in the KKD-NT-treated group compared with the KKD-WA-treated group because of the protective function.

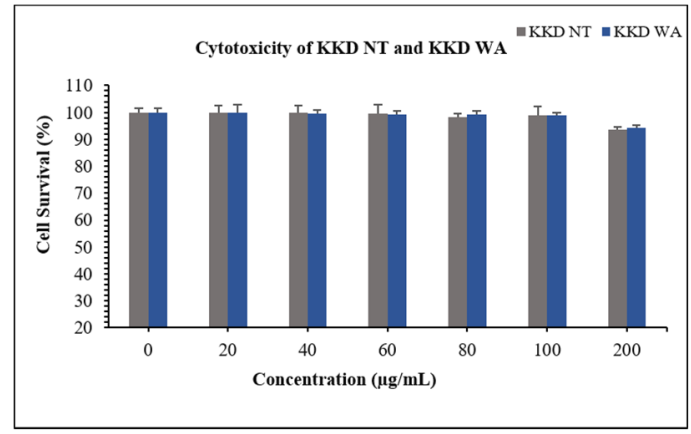

Figure 3. Cytotoxicity assessment using MTT in HepG2 following the incubation of various concentrations of KKD-NT and KKD-WA for $24 \mathrm{~h}$. Values are mean $\pm \mathrm{SE}$ of three independent experiments. 

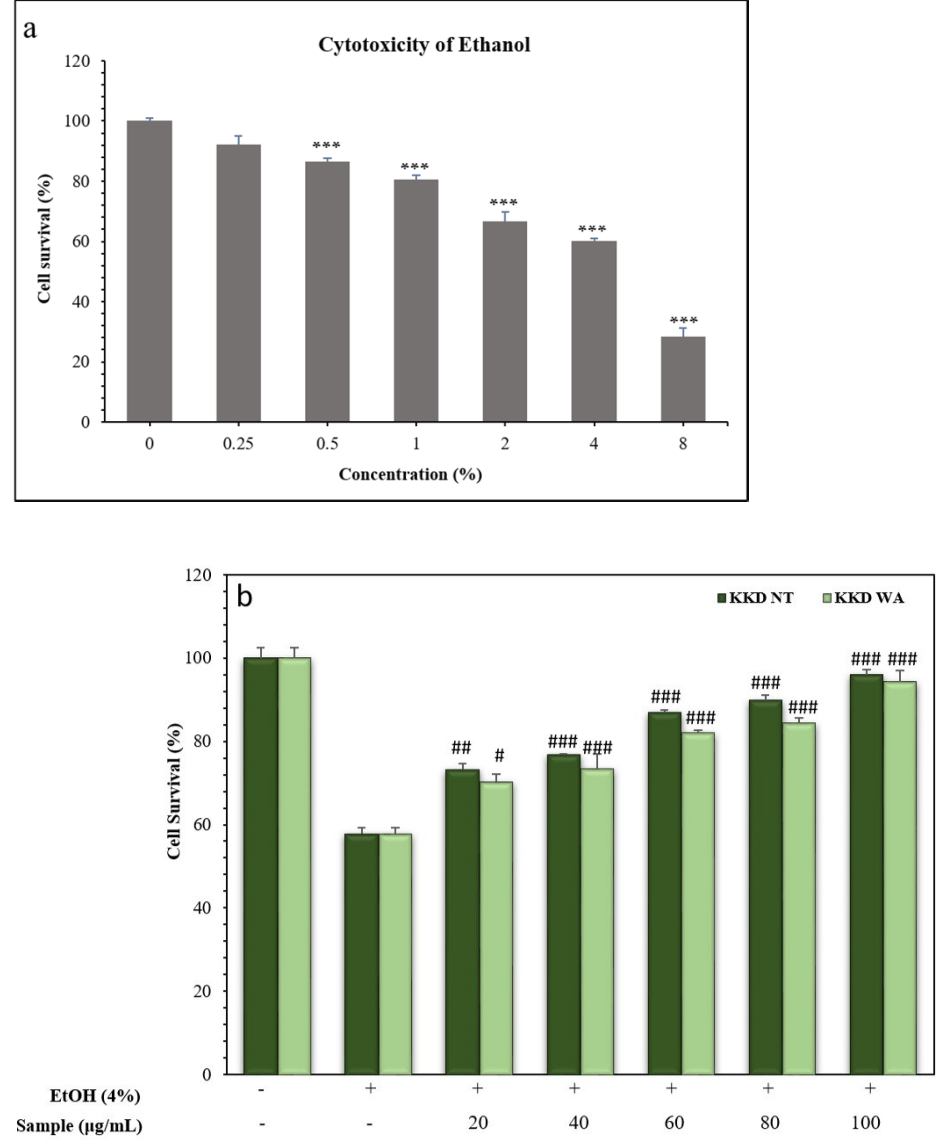

Figure 4. Measurement of cell viability of HepG2 following ethanol treatment. (a) Cells were treated with selected concentration of ethanol $(\mathrm{EtOH})$ for $24 \mathrm{~h}$; (b) cells were incubated with indicated concentrations of KKD-NT and KKD-WA in the presence of EtOH for $24 \mathrm{~h}$. Cell survival percentage was assessed using MTT assay as mentioned in materials and methods section. Values are means of three independent experiments $\pm \mathrm{SD}(n=3 \# p<0.05$, \#\# $p<0.01$, \#\#\# $p<0.001$ indicate differences from the ethanol-treated group. ${ }^{* * *} p<0.001$.

\subsection{Kakadu Plum Suppresses Elevated Levels of ROS in HepG2 Cells}

In normal conditions, ROS generation and their destruction by the cellular antioxidant system are balanced in our bodies. Alcohol administration causes oxidative stress along with an accumulation of intracellular ROS in hepatic cells, which play a vital role in the development of alcoholic liver disease [54]. In this study, alcohol exposure increased intracellular ROS generation in HEpG2 cells.

The Kakadu plum (T. ferdinandiana) exerts potential ROS-scavenging activity in Caco-2 and KERTr cells [55]. To examine whether the protective ability of KKD is associated with EtOH metabolism-mediated ROS formation in the hepatic cell culture models, we further quantified the cellular levels of ROS in the HepG2 cells. The ratio of NADH/NAD+ can be drastically changed by ethanol metabolism causing the ROS formation. As indicated in (Figure 5), 4\% EtOH notably increased ROS production compared to the control. As expected, the ethanol-mediated intracellular accumulation of ROS in the cells was abolished in a dose-dependent manner by KKD-NT and KKD-WA treatment. It is known that antioxidants can neutralize free radicals by giving up some of their own electrons and our sample has potential antioxidant properties. These results provide evidence of the inhibitory effect of KKD-NT and KKD-WA on ethanol-induced ROS production because of the higher antioxidant capacity of the fruits. Overall, the results show that KKD-NT inhibits ROS production in cells more significantly than KKD-WA as the antioxidant activity of KKD-NT exceeds KKD-WA. 


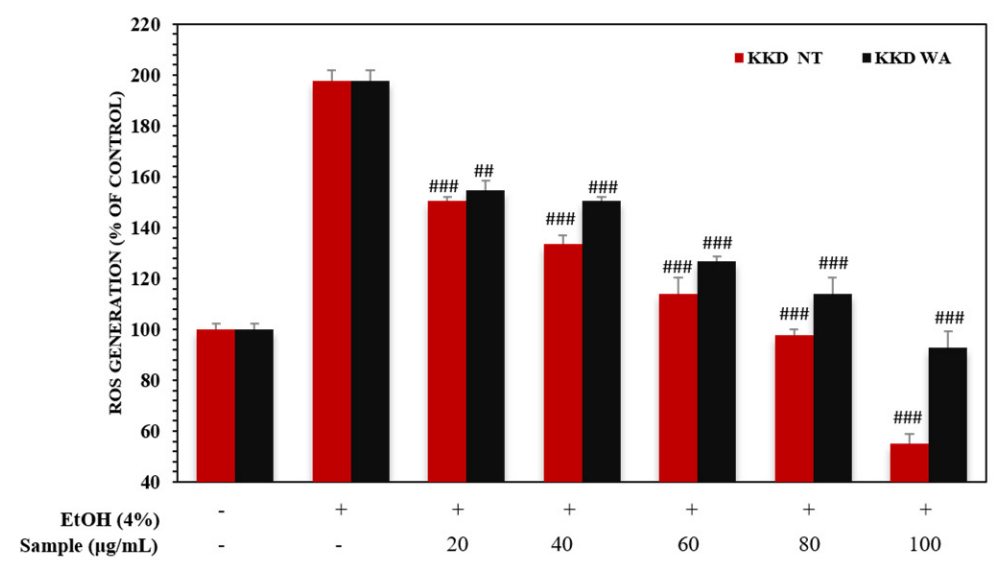

Figure 5. Effect of KKD-NT and KKD-WA on intracellular ROS levels in EtOH-induced HepG2 cells. Cells were treated with different concentrations of KKD-NT and KKD-WA in medium containing $4 \%$ EtOH. Values are expressed as mean $\pm \mathrm{SE}(n=3)$. \#\# $p<0.01$, \#\#\# $p<0.001$, compared with the EtOH control group.

\subsection{Effect of KKD-NT and KKD-WA on ADH and ALDH Activities}

Alcohol-induced mechanisms are closely related to the metabolism of ethanol, and the main enzymatic pathway is the ADH pathway. In the present study, we examined whether the KKD-NT and KKD-WA extracts could enhance the ADH/ALDH-mediated ethanol metabolism in liver cells. ADH/ALDH activities were evaluated from the enzymatic assays using HepG2 liver cells. ADH and ALDH activities increased dose-dependently when treated with KKD-NT and KKD-WA (Figure 6).
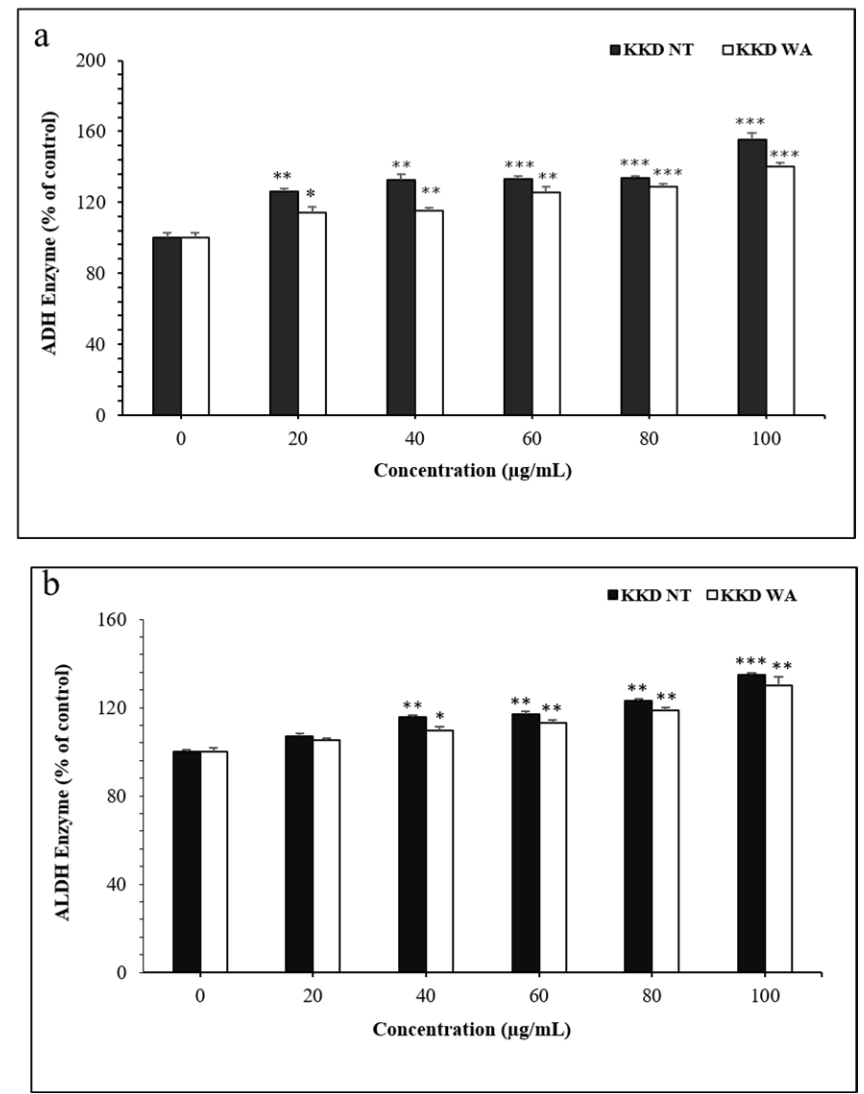

Figure 6. Activities of $\operatorname{ADH}(\mathbf{a})$ and $\operatorname{ALDH}(\mathbf{b})$. The activities of both of the enzymes were determined using the methods described in the Materials and Methods section. ${ }^{*} p<0.05,{ }^{* *} p<0.01,{ }^{* * *} p<0.001$ compared to control (CTL). 
ROS are generated by the excess ethanol in the metabolic pathways, and the ADHdependent removal of alcohol is a primary mechanism for the protection of liver cells from oxidative stress. Our results proposed that KKD-NT and KKD-WA increase ADH and ALDH enzymatic activity. As our samples contain Vit-C along with gallic acid, it is already proven that gallic acid can increase ADH and ALDH activities [56]. In addition, Vit-c has a protective effect against ascorbic acid equivalents, acetaldehyde, in alcoholism [34]. According to our results, KKD-NT and KKD-WA show a strong antioxidant and a potent catalytic factor to stimulate the alcohol metabolism-related enzymes.

\section{Conclusions}

The results of this study indicate that the extracts of KKD-NT and KKD-WA contain a higher level of ascorbic acid than other oranges available. The results showed that the appropriate concentrations of KKD have potential efficacy to protect liver cells from EtOH-induced cytotoxicity. Furthermore, the extracts of Kakadu Plum (KKD-NT and KKD-WA) were found to exert significant alcohol detoxification properties along with strong, promising antioxidant activities and showed a capability for free radical scavenging in HepG2 cells. Moreover, the Kakadu plum extracts promoted the activities of two major enzymes (ADH and ALDH) related to alcohol metabolism in the enzymatic assay. Taken together, our results demonstrate that the Kakadu plum can be a promising therapeutic agent in the prevention of liver damage caused by alcohol.

Author Contributions: Conceptualization, R.A.; data curation, R.A., G.-Y.K., and J.C.A.; formal analysis, R.M. and Z.M.R.; investigation, R.M.; methodology, R.A., G.-Y.K., and J.C.A.; project administration, D.C.Y. and S.C.K.; writing-original draft, R.A. All authors have read and agreed to the published version of the manuscript.

Funding: This work was supported by the Korean Institute of Planning and Evaluation for Technology in Food, Agriculture, and Forestry (IPET) through the High Value-added Food Technology Development Program, funded by the Ministry of Agriculture, Food and Rural Affairs (MAFRA) (317041-5).

Institutional Review Board Statement: Not applicable.

Informed Consent Statement: Not applicable.

Data Availability Statement: We do not wish to make the data publicly available as further research is being undertaken based on this study.

Acknowledgments: This work was supported by the Korean Institute of Planning and Evaluation for Technology in Food, Agriculture and Forestry (IPET) through the High Value-added Food Technology Development Program, funded by the Ministry of Agriculture, Food and Rural Affairs (MAFRA) (317041-5).

Conflicts of Interest: The authors have no conflict of interest to declare. The authors alone are responsible for the content and writing of the article.

\section{References}

1. Park, J.H.; Kim, Y.; Kim, S.H. Green tea extract (Camellia sinensis) fermented by Lactobacillus fermentum attenuates alcoholinduced liver damage. Biosci. Biotechnol. Biochem. 2012, 76, 2294-2300. [CrossRef] [PubMed]

2. Sudeep, H.; Venkatakrishna, K.; Sundeep, K.; Vasavi, H.; Raj, A.; Chandrappa, S.; Shyamprasad, K. Turcuron: A standardized bisacurone-rich turmeric rhizome extract for the prevention and treatment of hangover and alcohol-induced liver injury in rats. Pharmacogn. Mag. 2020, 16, 263. [CrossRef]

3. Bobasa, E.M.; Phan, A.D.T.; Manolis, C.; Netzel, M.; Smyth, H.; Cozzolino, D.; Sultanbawa, Y. Effect of sample presentation on the near infrared spectra of wild harvest Kakadu plum fruits (Terminalia ferdinandiana). Infrared Phys. Technol. 2020, 111, 103560. [CrossRef]

4. Yang, X.; Zhang, T.; Zhang, H.; Sang, S.; Chen, H.; Zuo, X. Temporal trend of gastric cancer burden along with its risk factors in China from 1990 to 2019, and projections until 2030: Comparison with Japan, South Korea, and Mongolia. Biomark. Res. 2021, 9 , 1-15. [CrossRef] [PubMed]

5. $\quad$ Li, Y.; Eshak, E.S.; Shirai, K.; Liu, K.; Dong, J.Y.; Iso, H.; Tamakoshi, A.; JACC Study Group. Alcohol Consumption and Risk of Gastric Cancer: The Japan collaborative cohort study. J. Epidemiol. 2021, 31, 30-36. 
6. Jung, K.-W.; Won, Y.-J.; Oh, C.-M.; Kong, H.-J.; Lee, D.H.; Lee, K.H. Cancer statistics in Korea: Incidence, mortality, survival, and prevalence in 2014. Cancer Res. Treat. 2017, 49, 292. [CrossRef]

7. Panchenko, L.; Davydov, B.; Terebilina, N.; Baronets, V.Y.; Zhuravleva, A. Oxidative stress in the alcoholic liver disease. Biochem. (Mosc.) Suppl. Ser. B Biomed. Chem. 2014, 8, 73-76. [CrossRef]

8. Ohashi, K.; Pimienta, M.; Seki, E. Alcoholic liver disease: A current molecular and clinical perspective. Liver Res. 2018, 2, 161-172. [CrossRef] [PubMed]

9. Goc, Z.; Kapusta, E.; Formicki, G.; Martiniaková, M.; Omelka, R. Effect of taurine on ethanol-induced oxidative stress in mouse liver and kidney. Chin. J. Physiol. 2019, 62, 148. [CrossRef]

10. Lee, S.I.; Kim, H.J.; Boo, Y.C. Effect of green tea and (-)-epigallocatechin gallate on ethanol-induced toxicity in HepG2 cells. Phytother. Res. 2008, 22, 669-674. [CrossRef]

11. Hyun, J.; Han, J.; Lee, C.; Yoon, M.; Jung, Y. Pathophysiological Aspects of Alcohol Metabolism in the Liver. Int. J. Mol. Sci. 2021, 22, 5717. [CrossRef] [PubMed]

12. Zakhari, S. Overview: How is alcohol metabolized by the body? Alcohol Res. Health 2006, $29,245$.

13. Vairappan, B. Cholesterol Regulation by Leptin in Alcoholic Liver Disease. In Molecular Aspects of Alcohol and Nutrition; Elsevier: Amsterdam, The Netherlands, 2016; pp. 187-200.

14. Ghazali, R.; Patel, V.B. Alcohol metabolism: General aspects. In Molecular Aspects of Alcohol and Nutrition; Elsevier: Amsterdam, The Netherlands, 2016; pp. 17-21.

15. Sha, K.; Choi, S.-H.; Im, J.; Lee, G.G.; Loeffler, F.; Park, J.H. Regulation of ethanol-related behavior and ethanol metabolism by the Corazonin neurons and Corazonin receptor in Drosophila melanogaster. PLoS ONE 2014, 9, e87062. [CrossRef] [PubMed]

16. Wu, D.; Cederbaum, A.I. Alcohol, oxidative stress, and free radical damage. Alcohol Res. Health 2003, 27, 277. [PubMed]

17. Poljsak, B.; Milisav, I. NAD+ as the link between oxidative stress, inflammation, caloric restriction, exercise, DNA repair, longevity, and health span. Rejuvenation Res. 2016, 19, 406-413. [CrossRef]

18. Lu, Y.; Cederbaum, A.I. CYP2E1 and oxidative liver injury by alcohol. Free. Radic. Biol. Med. 2008, 44, 723-738. [CrossRef] [PubMed]

19. She, X.; Wang, F.; Ma, J.; Chen, X.; Ren, D.; Lu, J. In vitro antioxidant and protective effects of corn peptides on ethanol-induced damage in HepG2 cells. Food Agric. Immunol. 2016, 27, 99-110. [CrossRef]

20. Butterfield, D.A. Oxidative stress in neurodegenerative disorders. Antioxid. Redox Signal. 2006, 8, 1971-1973. [CrossRef]

21. Clarke, P.A. Aboriginal People and Their Plants; Rosenberg Publishing: Kenthurst, NSW, Australia, 2007.

22. Akter, S.; Netzel, M.E.; Fletcher, M.T.; Tinggi, U.; Sultanbawa, Y. Chemical and nutritional composition of Terminalia ferdinandiana (kakadu plum) kernels: A novel nutrition source. Foods 2018, 7, 60. [CrossRef]

23. Gorman, J.T.; Wurm, P.A.; Vemuri, S.; Brady, C.; Sultanbawa, Y. Kakadu Plum (Terminalia ferdinandiana) as a sustainable indigenous agribusiness. Econ. Bot. 2020, 74, 74-91. [CrossRef]

24. Brock, J. Native Plants of Northern Australia; Reed New Holland: Sydney, NSW, Australia, 2001.

25. Phan, A.D.T.; Damyeh, M.S.; Chaliha, M.; Akter, S.; Fyfe, S.; Netzel, M.E.; Cozzolino, D.; Sultanbawa, Y. The effect of maturity and season on health-related bioactive compounds in wild harvested fruit of Terminalia ferdinandiana (Exell). Int. J. Food Sci. Technol. 2021, 56, 6431-6442. [CrossRef]

26. Singh, A.; Bajpai, V.; Kumar, S.; Kumar, B.; Srivastava, M.; Rameshkumar, K. Comparative profiling of phenolic compounds from different plant parts of six Terminalia species by liquid chromatography-tandem mass spectrometry with chemometric analysis Ind. Crops Prod. 2016, 87, 236-246. [CrossRef]

27. Shami, A.-M.M.; Philip, K.; Muniandy, S. Synergy of antibacterial and antioxidant activities from crude extracts and peptides of selected plant mixture. BMC Complementary Altern. Med. 2013, 13, 360. [CrossRef]

28. Williams, D.J.; Edwards, D.; Pun, S.; Chaliha, M.; Burren, B.; Tinggi, U.; Sultanbawa, Y. Organic acids in Kakadu plum (Terminalia ferdinandiana): The good (ellagic), the bad (oxalic) and the uncertain (ascorbic). Food Res. Int. 2016, 89, 237-244. [CrossRef] [PubMed]

29. Sommano, S.; Caffin, N.; Kerven, G. Screening for antioxidant activity, phenolic content, and flavonoids from Australian native food plants. Int. J. Food Prop. 2013, 16, 1394-1406. [CrossRef]

30. Tan, A.C.; Konczak, I.; Ramzan, I.; Sze, D.M.-Y. Native Australian fruit polyphenols inhibit cell viability and induce apoptosis in human cancer cell lines. Nutr. Cancer 2011, 63, 444-455. [CrossRef] [PubMed]

31. Sirdaarta, J.; Matthews, B.; Cock, I. Kakadu plum fruit extracts inhibit growth of the bacterial triggers of rheumatoid arthritis: Identification of stilbene and tannin components. J. Funct. Foods 2015, 17, 610-620. [CrossRef]

32. Tan, A.C.; Konczak, I.; Ramzan, I.; Zabaras, D.; Sze, D.M.-Y. Potential antioxidant, antiinflammatory, and proapoptotic anticancer activities of Kakadu plum and Illawarra plum polyphenolic fractions. Nutr. Cancer 2011, 63, 1074-1084. [CrossRef] [PubMed]

33. Wright, M.H.; Sirdaarta, J.; Matthews, B.; Greene, A.C.; Cock, I.E. Growth Inhibitory Activity of Kakadu Plum Extracts Against the Opportunistic Pathogenclostridium Perfringens: New Leads in the Prevention and Treatment of Clostridial Myonecrosis. Pharmacogn. J. 2016, 8, 144-153. [CrossRef]

34. Sprince, H.; Parker, C.M.; Smith, G.G.; Gonzales, L.J. Protective action of ascorbic acid and sulfur compounds against acetaldehyde toxicity: Implications in alcoholism and smoking. Agents Actions 1975, 5, 164-173. [CrossRef]

35. Mohapatra, P.; Ray, A.; Jena, S.; Nayak, S.; Mohanty, S. Influence of extraction methods and solvent system on the chemical composition and antioxidant activity of Centella asiatica L. leaves. Biocatal. Agric. Biotechnol. 2021, 33, 101971. [CrossRef] 
36. Simu, S.Y.; Ahn, S.; Castro-Aceituno, V.; Singh, P.; Mathiyalangan, R.; Jiménez-Pérez, Z.E.; Yang, D. Gold nanoparticles synthesized with fresh panax ginseng leaf extract suppress adipogenesis by downregulating PPAR/CEBP signaling in 3T3-L1 mature adipocytes. J. Nanosci. Nanotechnol 2018, 18, 1-8.

37. Markus, J.; Mathiyalagan, R.; Kim, Y.-J.; Abbai, R.; Singh, P.; Ahn, S.; Perez, Z.E.J.; Hurh, J.; Yang, D.C. Intracellular synthesis of gold nanoparticles with antioxidant activity by probiotic Lactobacillus kimchicus DCY51T isolated from Korean kimchi. Enzym. Microb. Technol. 2016, 95, 85-93. [CrossRef]

38. Bhalodia, N.R.; Nariya, P.B.; Shukla, V.; Acharya, R. In vitro antioxidant activity of hydro alcoholic extract from the fruit pulp of Cassia fistula Linn. AYU (An Int. Q. J. Res. Ayurveda) 2013, 34, 209-214. [CrossRef]

39. Castro-Aceituno, V.; Ahn, S.; Simu, S.Y.; Singh, P.; Mathiyalagan, R.; Lee, H.A.; Yang, D.C. Anticancer activity of silver nanoparticles from Panax ginseng fresh leaves in human cancer cells. Biomed. Pharmacother. 2016, 84, 158-165. [CrossRef] [PubMed]

40. Ciuclan, L.; Ehnert, S.; Ilkavets, I.; Weng, H.-L.; Gaitantzi, H.; Tsukamoto, H.; Ueberham, E.; Meindl-Beinker, N.M.; Singer, M.V.; Breitkopf, K.; et al. TGF- $\beta$ enhances alcohol dependent hepatocyte damage via down-regulation of alcohol dehydrogenase I. J. Hepatol. 2010, 52, 407-416. [CrossRef]

41. Kim, B.Y.; Cui, Z.G.; Lee, S.R.; Kim, S.J.; Kang, H.K.; Lee, Y.K.; Park, D.B. Effects of Asparagus officinalis extracts on liver cell toxicity and ethanol metabolism. J. Food Sci. 2009, 74, H204-H208. [CrossRef] [PubMed]

42. Bobasa, E.M.; Phan, A.D.T.; Netzel, M.E.; Cozzolino, D.; Sultanbawa, Y. Hydrolysable tannins in Terminalia ferdinandiana Exell fruit powder and comparison of their functional properties from different solvent extracts. Food Chem. 2021, $358,129833$. [CrossRef]

43. Cozzolino, D.; Phan, A.D.T.; Netzel, M.E.; Smyth, H.; Sultanbawa, Y. The use of vibrational spectroscopy to predict vitamin C in Kakadu plum powders (Terminalia ferdinandiana Exell, Combretaceae). J. Sci. Food Agric. 2021, 101, 3208-3213. [CrossRef] [PubMed]

44. Cozzolino, D.; Phan, A.D.T.; Aker, S.; Smyth, H.E.; Sultanbawa, Y. Can Infrared Spectroscopy Detect Adulteration of Kakadu Plum (Terminalia ferdinandiana) Dry Powder with Synthetic Ascorbic Acid? Food Anal. Methods 2021, 14, 1936-1942. [CrossRef]

45. Courtney, R.; Sirdaarta, J.; Matthews, B.; Cock, I. Tannin components and inhibitory activity of Kakadu plum leaf extracts against microbial triggers of autoimmune inflammatory diseases. Pharmacogn. J. 2015, 7, 18-31. [CrossRef]

46. Phan, A.D.T.; Adiamo, O.; Akter, S.; Netzel, M.E.; Cozzolino, D.; Sultanbawa, Y. Effects of drying methods and maltodextrin on vitamin $\mathrm{C}$ and quality of Terminalia ferdinandiana fruit powder, an emerging Australian functional food ingredient. J. Sci. Food Agric. 2021, 101, 5132-5141. [CrossRef]

47. Richmond, R.; Bowyer, M.; Vuong, Q. Australian native fruits: Potential uses as functional food ingredients. J. Funct. Foods 2019, 62, 103547. [CrossRef]

48. Kaurinovic, B.; Vastag, D. Flavonoids and Phenolic Acids as Potential Natural Antioxidants; IntechOpen: London, UK, 2019. [CrossRef]

49. Netzel, M.; Netzel, G.; Tian, Q.; Schwartz, S.; Konczak, I. Native Australian fruits—a novel source of antioxidants for food. Innov. Food Sci. Emerg. Technol. 2007, 8, 339-346. [CrossRef]

50. Warinhomhoun, S.; Muangnoi, C.; Buranasudja, V.; Mekboonsonglarp, W.; Rojsitthisak, P.; Likhitwitayawuid, K.; Sritularak, B. Antioxidant Activities and Protective Effects of Dendropachol, a New Bisbibenzyl Compound from Dendrobium pachyglossum, on Hydrogen Peroxide-Induced Oxidative Stress in HaCaT Keratinocytes. Antioxidants 2021, 10, 252. [CrossRef] [PubMed]

51. Jadid, N.; Hidayati, D.; Hartanti, S.R.; Arraniry, B.A.; Rachman, R.Y.; Wikanta, W. Antioxidant activities of different solvent extracts of Piper retrofractum Vahl. using DPPH assay. In AIP Conference Proceedings, Proceeding of the International Biology Conference 2016: Biodiversity and Biotechnology for Human Welfare, Surabaya, Indonesia, 15 October 2016; Murkovic, M., Risuleo, G., Eds.; AIP Publishing LLC: Melville, NY, USA, 2017.

52. Farshori, N.N.; Al-Sheddi, E.S.; Al-Oqail, M.M.; Hassan, W.H.; Al-Khedhairy, A.A.; Musarrat, J.; Siddiqui, M.A. Hepatoprotective potential of Lavandula coronopifolia extracts against ethanol induced oxidative stress-mediated cytotoxicity in HepG2 cells Toxicol. Ind. Health 2015, 31, 727-737. [CrossRef]

53. Kim, T.-J.; Byun, J.-S.; Kwon, H.S.; Kim, D.-Y. Cellular toxicity driven by high-dose vitamin C on normal and cancer stem cells. Biochem. Biophys. Res. Commun. 2018, 497, 347-353. [CrossRef]

54. Kumar, K.S.; Chu, F.-H.; Hsieh, H.-W.; Liao, J.-W.; Li, W.-H.; Lin, J.C.-C.; Shaw, J.-F.; Wang, S.-Y. Antroquinonol from ethanolic extract of mycelium of Antrodia cinnamomea protects hepatic cells from ethanol-induced oxidative stress through Nrf-2 activation. J. Ethnopharmacol. 2011, 136, 168-177. [CrossRef]

55. Chaliha, M.; Sultanbawa, Y. Terminalia ferdinandiana, a traditional medicinal plant of Australia, alleviates hydrogen peroxide induced oxidative stress and inflammation, in vitro. J. Complementary Integr. Med. 2020, 17, 20190008. [CrossRef]

56. Hur, J.M.; Park, J.C. Effects of the aerial parts of Orostachys japonicus and its bioactive component on hepatic alcohol-metabolizing enzyme system. J. Med. Food 2006, 9, 336-341. [CrossRef] 